\title{
WETLANDS ASSESSMENT FOR SITE CHARACTERIZATION, ADVANCED NEUTRON SOURCE (ANS)
}

October 1994

Prepared by the

Oak Ridge National Laboratory

Oak Ridge, Tennessee 37831 managed by

Martin Marietta Energy Systems, Inc.

for the

U.S. DEPARTMENT OF ENERGY

under Contract No. DE-AC05-84OR21400 


\section{DISCLAIMER}

This report was prepared as an account of work sponsored by an agency of the United States Government. Neither the United States Government nor any agency thereof, nor any of their employees, make any warranty, express or implied, or assumes any legal liability or responsibility for the accuracy, completeness, or usefulness of any information, apparatus, product, or process disclosed, or represents that its use would not infringe privately owned rights. Reference herein to any specific commercial product, process, or service by trade name, trademark, manufacturer, or otherwise does not necessarily constitute or imply its endorsement, recommendation, or favoring by the United States Government or any agency thereof. The views and opinions of authors expressed herein do not necessarily state or reflect those of the United States Government or any agency thereof. 


\section{DISCLAIMER}

Portions of this document may be illegible in electronic image products. Images are produced from the best available original document. 


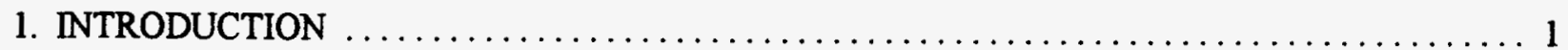

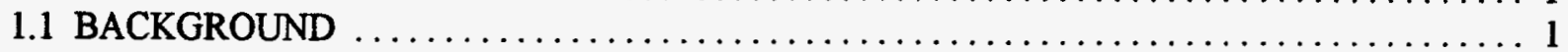

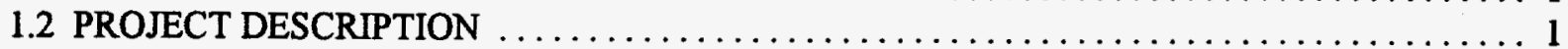

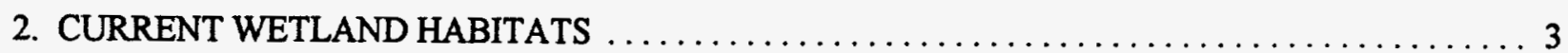

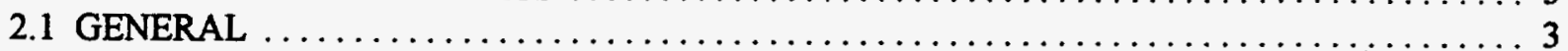

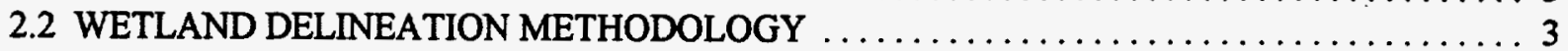

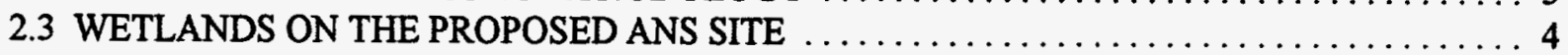

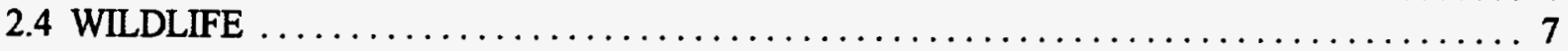

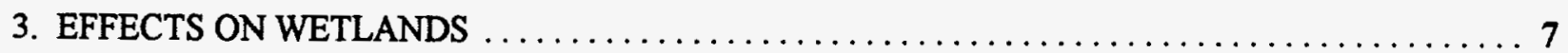

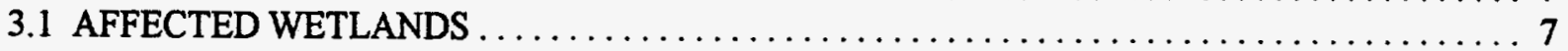

3.2 POTENTIAL IMPACTS OF WETLAND DISTURBANCE $\ldots \ldots \ldots \ldots \ldots \ldots \ldots \ldots, \ldots$

4. WETLANDS MITIGATION AND RESTORATION $\ldots \ldots \ldots \ldots \ldots \ldots \ldots \ldots \ldots \ldots \ldots \ldots \ldots$

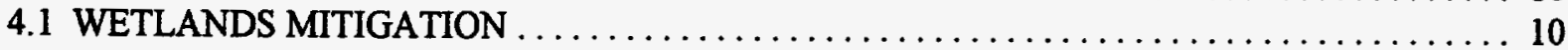

4.2 WELL SITE AND ROAD CROSSING RESTORATION $\ldots \ldots \ldots \ldots \ldots \ldots \ldots \ldots \ldots \ldots \ldots$

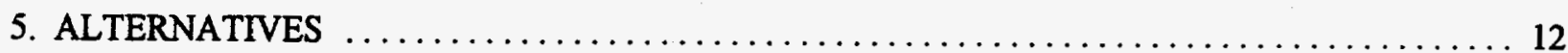

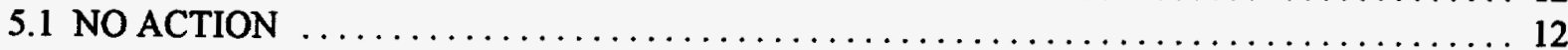

5.2 OTHER ALTERNATIVES $\ldots \ldots \ldots \ldots \ldots \ldots \ldots \ldots \ldots \ldots \ldots \ldots \ldots \ldots \ldots \ldots \ldots \ldots, 13$

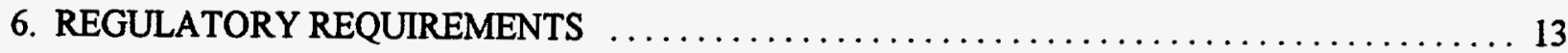

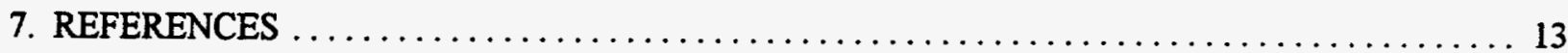

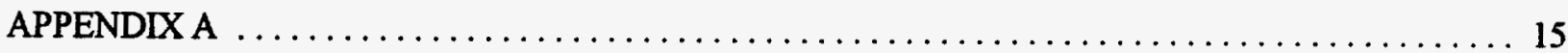

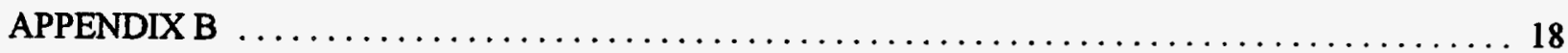




\section{LIST OF FIGURES}

Figure

$\underline{\text { Page }}$

1. Location of the ANS site on the Oak Ridge Reservation $\ldots \ldots \ldots \ldots \ldots \ldots \ldots \ldots \ldots \ldots$

2. Proposed boring locations (B) and identified wetlands (WL) of the ANS facility .........8

\section{LIST OF TABLES}

Table

Page

1. Classification of plant species by probability of occurrence in wetlands $\ldots \ldots \ldots \ldots \ldots \ldots .4$

2. List of plant species and their wetland indicator classifications identified during wetland surveys of selected areas of the proposed ANS site 4

3. Wetland areas near proposed boring locations $\ldots \ldots \ldots \ldots \ldots \ldots \ldots \ldots \ldots \ldots \ldots$

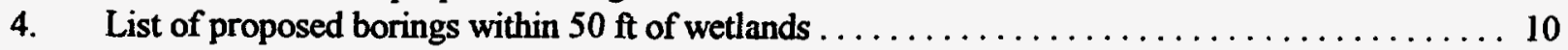




\section{WETLANDS ASSESSMENT FOR SITE CHARACTERIZATION, ANS}

\section{INTRODUCTION}

This Wetlands Assessment has been prepared in accordance with the Department of Energy's (DOE) Code of Federal Regulations (CFR) 10 CFR 1022, Compliance with Floodplain/Wetlands Environmental Review Requirements, which established the policy and procedure for implementing Executive Order 11990, Protection of Wetlands. The proposed action is to conduct characterization activities in or near wetlands at the ANS site. The proposed action will be covered under a Categorical Exclusion, therefore this assessment is being prepared as a separate document [10 CFR 1022.12(c)]. The purpose of this Wetlands Assessment is to fulfill the requirements of 10 CFR 1022.12(a) by describing the project, discussing the effects of the proposed action upon the wetlands, and considering alternatives to the proposed action.

\subsection{BACKGROUND}

The proposed action would take place at the proposed preferred site for the Advanced Neutron Source (ANS) facility at the Oak Ridge National Laboratory (ORNL) in Oak Ridge, Tennessee. The proposed ANS site covers approximately 100 acres at the intersection of Melton Valley Drive and the Health Physics Research Reactor (HPRR) Access Road (Fig. 1). The site straddles the watershed divide of Melton Valley and Bearden Creek with the majority of the site located in the Melton Valley. The proposed ANS site consists of rolling to steep uplands dissected by headwater, tributary bottomlands. The site is under secondary growth hardwoods with an estimated age of thirty to forty years.

The ANS facility would consist of a $330 \mathrm{MW}$ heavy water cooled and moderated reactor to provide a source of neutrons for experimental purposes. Site characterization activities are required to define subsurface conditions that exist under ANS structures and to define engineering data necessary to proceed with the ANS design.

\subsection{PROJECT DESCRIPTION}

The proposed site characterization activities include boring approximately 73 holes to varying depths (approximately $150 \mathrm{ft}$ ) in the subsurface rock structure, retrieving the soil samples, rock core, and performing engineering tests on the soil samples and the rock cores and perform in situ tests in the holes to identify subsurface rock characteristics. Access to the boring locations will be provided by $12 \mathrm{ft}$ wide crushed stone roads installed over geotextile fabric. Some of these roads may cross stream channels. The proposed boring 


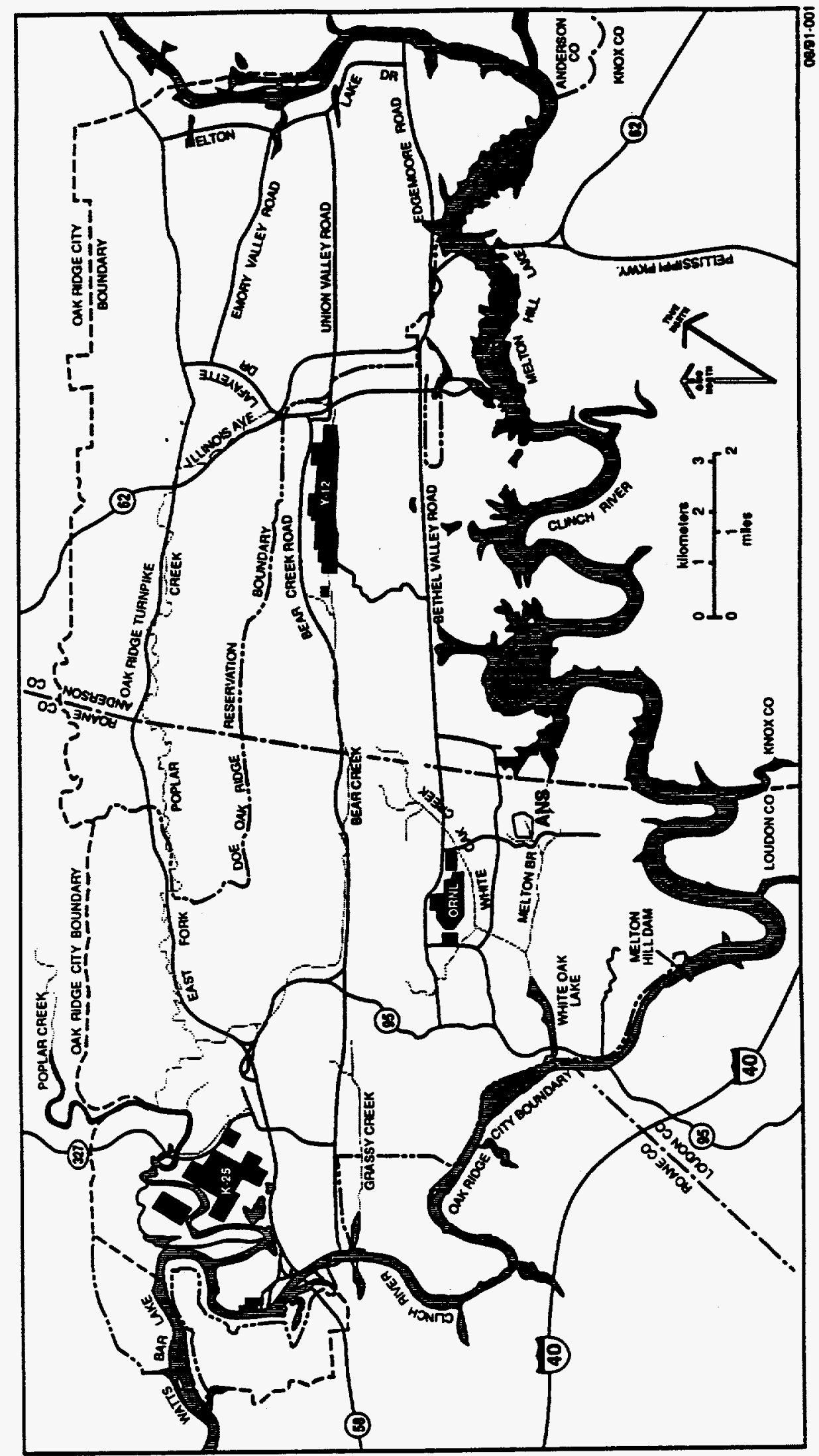

 
program will be conducted in phases. The number and exact locations of the borings is dependent on information obtained in the earlier phases. Each boring location will require up to a $50 \mathrm{ft}$ by $50 \mathrm{ft}$ drilling pad. The size of the pad is dependent on the orientation of the access road as well as the topography in the immediate vicinity of the boring. The drilling pad would be constructed of a 4 in. thick layer of crushed rock over geotextile fabric. The water used as a drilling lubricant would be contained in an earthen dike and allowed to percolate back into the soil. Drilling waste from the hole would be evenly distributed over the site. Current plans are for the holes to be capped, locked, and identified for possible reentry later for additional tests. This may be revised following the initial borings if subsurface conditions are conducive to collapse of the holes. When a determination is made that information is complete, the bore holes will be filled with a cement grout; except for those selected as permanent monitoring wells. All drilling will be conducted in accordance with the ANS Quality Assurance Plan (Law Engineering 1993) and the ORNL Typical Operating Procedure (TOP) for Building Site Soil Characterization Studies, TOP-001.

\section{CURRENT WETLAND HABITATS}

\subsection{GENERAL}

The proposed site is in the headwater areas of the Melton Branch and Bearden Creek Watersheds and in the Clinch River drainage. Melton Branch and Bearden Creek do not occur on the ANS site; however, principal tributaries of these streams cross the site. The Melton Branch tributary (Melton Branch North Tributary 1) is formed by several headwater subtributaries that begin on the lower slopes of Haw Ridge and join in the bottomland area south of Melton Valley Drive and east of the HPRR Access Road. Another subtributary begins on the east side of the HPRR Access Road and joins the main tributary in the southwest corner of the site, west of the HPRR Access Road. The Bearden Creek tributary crosses the northeastern portion of the site. This tributary has four subtributaries that flow from the lower slopes of Haw Ridge and one subtributary and a wet-weather conveyance that flow from side ridges to the south. Two additional Bearden Creek subtributaries are located offsite to the south.

The primary vegetation communities on the site are mixed hardwood forest dominated by oaks (Quercus spp.) on the side slopes and ridgetops, and riparian hardwood forests dominated by sweetgum (Liquidambar styriciflua), red maple (Acer rubrum), green ash (Fraxinus pennsylvanicus), and ironwood (Carpinus caroliniana) in the stream bottoms.

\subsection{WETLAND DELINEATION METHODOLOGY}

The field methodology for wetland identification on the ANS site is based on the 1987 U.S. Army Corps of Engineers (USACOE) Wetlands Delineation Manual. In 33 CFR 328.3(b), the USACOE defines wetlands 
as, "Those areas that are inundated or saturated by surface or ground water at a frequency and duration sufficient to support, and that under normal circumstances do support, a prevalence of vegetation typically adapted for life in saturated soil conditions." In accordance with USACOE method, the following three characteristics are diagnostic of wetlands:

a. Hydrophytic Vegetation-The prevalent vegetation consists of macrophytes typically adapted to wetland soil and hydrological conditions. The U.S. Fish and Wildlife Service (Reed 1988) has developed a classification scheme that assigns species to wetland indicator classes according to the probability of occurrence (expressed as a percentage) in a wetland (Table 1). If greater than 50 percent of the dominant vegetation in each plant strata consists of species that have an indicator status of OBL, FACW, and/or FAC, the vegetation is classified as hydrophytic.

Table 1. Classification of plant species by probability of occurrence in wetlands

\begin{tabular}{lc}
\hline \multicolumn{1}{c}{ Classification } & Percent occurrence in wetlands \\
\hline Obligate wetland (OBL) & $>99$ \\
Facultative wetland (FACW) & $67-99$ \\
Facultative (FAC) & $34-66$ \\
Facultative upland (FACU) & $1-33$ \\
Upland & $<1$ \\
\hline
\end{tabular}

b. Hydric Soil-Hydric soils are soils that are saturated, flooded, or ponded long enough during the growing season to develop anaerobic conditions in a major part of the root zone.

c. Wetland Hydrology-The area is inundated either permanently or periodically at depths less than $6.6 \mathrm{ft}$, or the soil is saturated to the surface at some time during the growing season of the prevalent vegetation.

\subsection{WETLANDS ON THE PROPOSED ANS SITE}

Forested wetlands were delineated along most or all of the length of the Melton Branch tributaries and subtributaries, and in small areas along the Bearden Creek tributary and subtributaries. The largest area of wetlands in the vicinity of the proposed borings is in the Melton Branch subdrainage (approximately 7.65 acres total). There are about 0.35 acres of wetlands near the boring locations in the Bearden Creek subwatershed. Unlike the Melton Branch tributary bottomlands, which are mostly forested wetlands, only scattered, small or narrow wetlands were identified in the Bearden Creek bottomlands.

The dominant plant species in the forested wetlands include sweetgum, green ash, red maple, slippery elm, ironwood, blackgum, spicebush in the canopy, subcanopy, and shrub layer. Species in the herbaceous layer include microstegium, bulbous bittercress, sedges, bugleweed, bedstraw, veined skullcap, jewelweed, 
hooked buttercup, Japanese honeysuckle, and poison ivy. A list of plant species found in the wetlands with their scientific names and indicator classifications is presented in Table 2.

Table 2. List of plant species and their wetland indicator classifications identified during wetland surveys of selected areas of the proposed ANS site

\begin{tabular}{|c|c|c|}
\hline Common name & Scientific name & Regional indicator \\
\hline \multicolumn{3}{|l|}{ TREES } \\
\hline American Elm & Ulmus americanus & FACW \\
\hline American Hornbeam & Carpinus caroliniana & FAC \\
\hline Black Cherry & Prunus serotina & FACU \\
\hline Black Tupelo (Black Gum) & Nyssa sylvatica & FAC \\
\hline Black Willow & Salix nigra & OBL \\
\hline Flowering Dogwood & Cornus florida & FACU \\
\hline Green Ash & Fraxinus pennsylvanica & FACW \\
\hline Red Maple & Acer rubrum & FAC \\
\hline Slippery Elm & Ulmus rubra & FAC \\
\hline Southern Red Oak & Quercus falcata & FACU \\
\hline Sweetgum & Liquidambar styriciflua & FAC \\
\hline Sycamore & Platanus occidentalis & FACW \\
\hline Tulip Poplar & Liriodendron tulipifera & FAC \\
\hline White Oak & Quercus alba & FACU \\
\hline \multicolumn{3}{|l|}{ SHRUBS } \\
\hline Northern Spicebush & Lindera benzoin & FACW \\
\hline Privet & Ligustrum vulgare & not listed \\
\hline Smooth Alder & Alnus serrulata & FACW \\
\hline \multicolumn{3}{|l|}{ VINES } \\
\hline American Potato-bean & Apios americana & FACW \\
\hline Hog Peanut & Amphicarpaea bracteata & FAC \\
\hline Japanese Honeysuckle & Lonicera japonica & FAC \\
\hline Poison Ivy & Toxicodendron radicans & FAC \\
\hline Virginia Creeper & Parthenocissus quinquefolia & FAC \\
\hline \multicolumn{3}{|l|}{ GRASSES } \\
\hline$\overline{\text { Fowl Manna Grass }}$ & Glyceria striata & OBL \\
\hline Kentucky Fescue & Festuca arundinacea & FAC \\
\hline Microstegium & Eulalia viminea & FAC \\
\hline Rice Cutgrass & Leersia oryzoides & OBL \\
\hline
\end{tabular}


Table 2. Continued

\section{SEDGES AND RUSHES}

Soft Rush

Green Bulrush

Leafy Bulrush

Baileys Sedge

Blunt Broom Sedge

Fox Sedge

Frank's Sedge

Fringed Sedge

Sallow Sedge

Blunt Spikerush

Creeping Spikerush

Juncus effusus

Scirpus atrovirens

Scirpus polyphyllus

Carex baileyi

Carex tribuloides

Carex vulpinoidea

Carex frankii

Carex crinita

Carex lurida

Eleocharis obtusa

Eleocharis palustris
FACW

OBL

OBL

FACW

FACW

OBL

OBL

OBL

OBL

OBL

OBL

\section{HERBACEOUS SPECIES}

Bugleweed

Bulbous Bittercress

Buttercup, bulbous

Buttercup, hooked

Cardinal Flower

Cattail

Cut-leaved Water Horehound

Dotted Smartweed

False Nettle

Great Blue Lobelia

Ironweed

Jewelweed

Marsh Bedstraw

Square-stemmed Monkeyflower

Swamp Smartweed

Veined Skullcap

Virginia Knotweed
Lycopus virginicus $\quad$ OBL

Cardamine bulbosa OBL

Ranunculus bulbosus $\quad$ FAC

Ranunculus recurvatus $\quad$ FAC

Lobelia cardinalis OBL

Typha latifolia OBL

Lycopus americanus $\quad$ OBL

Polygonum punctatum $\quad$ FACW

Boehmeria cylindrica FACW

Lobelia syphilitica OBL

Vernonia noveboracensis $\quad$ FAC

Impatiens capensis $\quad$ FACW

Galium tinctorium FACW

Mimulus ringens $\quad$ OBL

Polygonum hydropiperoides OBL

Scutellaria nervosa FAC

Polygonum virginianum $\quad$ FAC

Regional indicators are from Reed, P. B., 1988. National List of Plant Species That Occur in Wetiands: Tennessee, USFWS Biological Report NERC-88/18.42. The indicator classification is based on the frequency with which a species occurs in a wetland habitat shown in Table 1.

There is little variation in the hydric characteristics of the soils found in the ANS wetlands. The matrix colors within the top 12 inches are generally gray or grayish brown. The most common mottles are brown, yellowish brown, and very dark gray. The soil also contains manganese concretions.

The primary hydrologic source for the onsite wetlands is groundwater from seeps and springs and shallow subsurface runoff from precipitation. On the days of the delineation (February 1993) the soils were 
saturated to the surface in all wetland locations, and there was standing free water in most of the wetland survey sample holes. Water was ponded on the surface, and where the streambanks are shallow, the streamflow had spread out into several shallow surface channels. During the wetland vegetation survey conducted on May 18,20, and 27, 1993, the depth to standing free water in the sample holes was greater than that noted during the February delineation; although the soils remained saturated or very moist. The adjacent upland soils were dry and easily crumbled.

\subsection{WILDLIFE}

In 1989, surveys were completed for terrestrial and aquatic wildife on the proposed ANS site including the wetland areas. No endangered or threatened terrestrial species are known to occupy the Oak Ridge Reservation or the ANS site (Appendix A). The Cooper's hawk (Accipiter cooperii), a state listed threatened species, could occur on the site but has not been observed. Disturbance to the forest at this site would decrease the amount of available forest habitat for this hawk and would impact other forest dwelling populations.

In spring 1992, one year prior to the wetland delineation, an active red-shouldered hawk's (Buteo lineatus) nest was found in the Melton Branch tributary bottomland adjacent to the proposed ANS site. The red-shouldered hawk is listed as a "Species in Need of Management" by the state of Tennessee. The nest was not observed to be active the year of the delineation. Red-shouldered hawks have been observed during several visits to Melton Valley and adjacent areas since then. The moist bottomlands provide good foraging and nesting habitat for this hawk.

Fish and invertebrates were surveyed in 1989 in streams potentially affected by the construction of the proposed ANS facility (Appendix B). On Melton Branch, downstream of the ANS site, blacknose dace (Rhinichthys atratulus) and creek chub (Semotilus atromaculatus) were collected. Numerous salamander larvae were found during the survey of Bearden Creek, but no fish were identified. Benthic invertebrate populations were found to be relatively diverse on upper Melton Branch and a tributary of Bearden Creek. It was concluded that impacts to fish populations will, as a result of developing the ANS project, be minimal if best management practices were employed for road construction and vegetation removal.

\section{EFFECTS ON WETLANDS}

\subsection{AFFECTED WETLANDS}

The proposed action includes drilling approximately 73 holes on the ANS site. Approximately 8 acres of wetlands have been identified near the proposed boring locations (Fig. 2). Up to 6.8 acres of wetlands may be affected by the site characterization work (i.e., drilling and installation of the drill pads). The 6.8 acre 

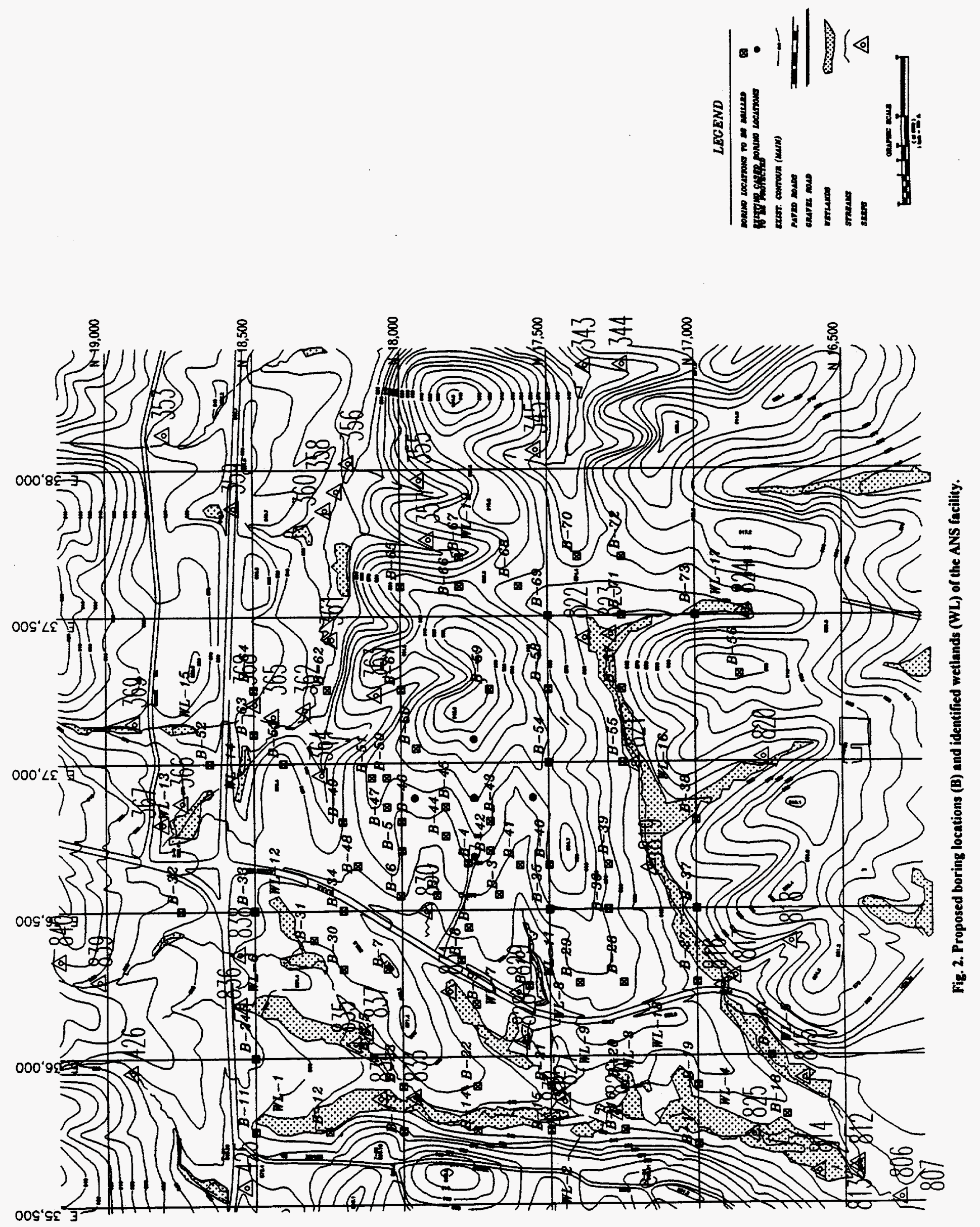
figure was determined by analyzing all the wetlands that occur within $50 \mathrm{ft}$ of a proposed boring (see Tables 3 and 4). The $50 \mathrm{ft}$ limit was determined since each boring drill pad may require up to a $50 \mathrm{ft}$ by $50 \mathrm{ft}$ area. Since the drill pads must be established with the actual boring location near the edge of the pad to accommodate equipment, this estimate of 6.8 acres is considered conservative. If terrain near the boring is relatively level, and the boring is not actually in the wetland, the drill pad can be constructed adjacent to the wetland with no direct impact (see Sect. 4.1). It is not certain how many additional acres of wetlands, floodplains, or streams would be affected by the access roads necessary to get to the boring locations.

Table 3. Wetland areas near proposed boring locations. Asterisks indicate wetlands within $50 \mathrm{ft}$ of the proposed boring totalling 6.8 acres. Overall total wetlands in the vicinity of the proposed borings are approximately 8 acres.

\begin{tabular}{cccc} 
Wetland number & Acreage & Wetland number & Acreage \\
\hline WL-1 & $1.39^{*}$ & WL-11 & 0.13 \\
WL-2 & 0.1 & WL-12 & $0.31^{*}$ \\
WL-3 & $0.25^{*}$ & WL-13 & 0.24 \\
WL-4 & $0.88^{*}$ & WL-14 & $0.1^{*}$ \\
WL-5 & $0.67^{*}$ & WL-15 & 0.01 \\
WL-6 & $0.73^{*}$ & WL-16 & $2.24^{*}$ \\
WL-7 & 0.46 & WL-17 & $0.17^{*}$ \\
WL-8 & 0.04 & WL-18 & 0.2 \\
WL-9 & $0.09^{*}$ & WL-19 & 0.02 \\
WL-10 & 0.02 & & \\
& Total & & $8.05(6.8)^{*}$ \\
\hline
\end{tabular}

\subsection{POTENTIAL IMPACTS OF WETLAND DISTURBANCE}

Site characterization activities occurring in the wetlands can lead to a loss of wetland functions, changes in stream water quality, and impacts to aquatic and terrestrial biota. Headwater wetlands can provide attenuation of stormflows, food chain support (through transformation of nutrients, such as carbon and nitrogen, and vegetation production), habitat and species diversity, and protection of downstream water quality and stream stability through removal of particulates and reduction in stormflow velocities. It is 
probable that these and other functions are operating to some extent in the potential affected wetlands on this site.

Table 4. List of proposed borings within $50 \mathrm{ft}$ of wetlands

\begin{tabular}{cc}
\hline Boring number & Wetland area \\
\hline B-11, B-12, B-14, B-15, B-23 & WL-1 \\
B-16, B-20 & WL-3 \\
B-17, B-18, B-19 & WL-4 \\
B-21 & WL-9 \\
B-25 & WL-6 \\
B-26 & WL-5 \\
B-27, B-37, B-38, B-55, B-57, B-71 & WL-16 \\
B-30, B-31, B-33 & WL-12 \\
B-63 & WL-14 \\
B-67 & WL-19 \\
B-73 & WL-17
\end{tabular}

The immediate effects of well drilling activities will be disturbance of up to 6.8 acres of wetlands, loss of forest and riparian vegetation, and soil disturbance. This is less than two percent of the wetlands that occur on the Oak Ridge Reservation. Potential impacts include siltation and temperature increases in the streams, changes in stream water chemistry, reduction or loss of aquatic macroinvertebrate populations (and subsequent food chain impacts), and increases in storm nunoff velocities. The terrestrial wildlife populations most likely to be impacted from the installation of the drill pads and roads would be forest dependent bird species. If best management practices and appropriate mitigative measures (Sect. 4.1) are employed, impacts to wetlands, wildlife populations, stream biota, and stream water quality will be minimized.

\section{WETLANDS MITIGATION AND RESTORATION}

\subsection{WETLANDS MITIGATION}

Wetlands mitigation is a step-wise decision-making process. The process is an evaluation of options that range from no impact to wetlands (avoidance), which is usually the preferred alternative, to compensatory mitigation (wetland creation, restoration, or enhancement), which is usually viewed as the alternative of last resort. In between these two options is minimization in which unavoidable impacts to wetlands are minimized 
through reducing the area of disturbance, using best management practices, and site restoration. Site restoration may also be considered within the scope of compensatory mitigation (see Sect. 4.2).

Therefore, the first step in considering mitigation for the site characterization activities is to determine the areas in which the necessary work can be accomplished without wetland disturbance. The second step is to develop plans to minimize impacts in those areas for which wetland disturbance is unavoidable. The following list of guidelines based on both the avoidance and minimization options, will be followed in developing final plans which depict boring locations, access roads, and wetlands. All guidelines carry equal weight; therefore, this list is not arranged in any order of importance or priority.

1. Use existing roads (e.g., utility line roads or old well roads) for access, whenever possible.

2. Locate borings and pads and access roads, where possible, outside the identified wetlands.

3. Disturbance to the forest at this site will be limited as much as practicable in order to protect forest habitat important to the Cooper's hawk and Red-Shouldered hawk as well as other forest dependent wildlife.

4. The site characterization activities will be contained within sufficient runoff controls (e.g., silt curtains) to prevent the addition of silt loads to the streams.

5. No activities should occur in areas that would impact mapped seeps (see Fig. 2).

6. Any road crossing of streams and drainage swales will be done in a manner that will allow continued flow during normal rainfall periods and limit addition of silt.

7. Access road construction and well drilling during wet periods will employ special precautions to prevent erosion.

8. If site characterization activities are near streams, buffer strips along the stream channels will be left as wide as reasonably possible to reduce runoff and to maintain shading of the stream to prevent altering the natural thermal regime.

Best management practices, including the following:

1. The topsoil and hydric soils in the wetlands will be covered with geotextile fabric, prior to the placement of crushed rock.

2. A gravel pad or skids (skids are preferable because of easier removal) should be put in place to support the drilling rig and other equipment.

3. Staked haybales and silt fence should be placed around the downslope side of the proposed roads and pad areas prior to any soil removal or disturbance. 


\subsection{DRILL PAD AND ROAD CROSSING RESTORATION}

After final plans of boring locations and access roads have been completed, wetlands to be impacted will be identified. Drill pads and roads to be in these wetland areas will be constructed last. The reasoning for this is that by the time the upland boring locations are constructed, the ultimate fate of the ANS project will be known. If ANS is canceled, these pads and roads in the wetlands will not be constructed. If ANS is to be built, the wetlands areas will be restored as discussed below.

As soon as possible after a determination to restore wetlands is made, the drilling pads and road crossings located wholly or partially in wetlands will be restored to a minimum level that will allow wetland vegetation and functions to naturally recover. Skid pads, geotextile fabric, and gravel will be removed. The area will be broadcast-seeded (not hydro-seeded) with annual ryegrass and annual legumes (i.e., crimson clover) to prevent erosion and discourage invasion of nearby exotic species such as Japanese honeysuckle and microstegium, and lightly mulched with straw (not hay as it carries too many seeds of exotic species). All erosion control devices will be removed once the annual cover has become well-established. It is anticipated that the surrounding herbaceous species would colonize these areas within one growing season and their abundance and diversity would increase with time to match that of the adjacent wetlands. The areas will be revisited to determine the extent and success of natural wetland development and regeneration and, if necessary, the site may have to be recontoured and planted in those woody plant species that existed prior to disturbance and are in the adjacent wetlands. These species may include red maple, sweetgum, sycamore, ironwood, smooth alder, and slippery elm. Upland access roads would also be seeded to an annual cover or native herbaceous species.

\section{ALTERNATIVES}

\subsection{NO ACTION}

If no action were taken, no boring holes, gravel pads, or gravel roads would be placed in the wetlands at the ANS site at ORNL and no associated impacts to the wetlands would occur as described above. However, not conducting the geotechnical site characterization activities would preclude the design, construction, and operation of the proposed ANS project. The proposed ANS project is expected to provide unique research capabilities (i.e., specific isotope production) for ORNL. Not allowing design and construction of ANS due the lack of appropriate site characterization is deemed unacceptable. 


\subsection{OTHER ALTERNATIVES}

There are no other actions that could substitute the proposed site characterization work, besides the no action, that would avoid the adverse effects on the wetlands expected under the proposed action. Therefore, no other alternatives are deemed practicable.

Part 1022.15(a) of DOE 10 CFR states, "If DOE finds that no practicable alternative to locating in the floodplain/wetlands is available, consistent with the policy set forth in Executive Order 11988, DOE shall, prior to taking action, design or modify its action in order to minimize potential harm to or within the floodplain/wetlands." Since no other alternatives are practicable for the characterization every effort will be made to avoid or mitigate impacts as has been discussed in Sect. 4.

\section{REGULATORY REQUIREMENTS}

Permits required for site characterization activities would include a permit from the USACOE and Aquatic Resource Alteration Permits (ARAP) from the State of Tennessee. The USACOE regulates activities in Waters of the U.S., including wetlands, under Section 404 of the Clean Water Act. The well drilling and road crossing activities may be authorized under Nationwide General Permits. Nationwide General Permits provide blanket authorization for certain types of activities in wetlands and do not (usually) have requirements for compensatory mitigation. The Tennessee Department of Environment and Conservation (TDEC 1987) regulates activities in Waters of the State, including wetlands. Activities in wetlands and other Waters of the State require an ARAP. There are no state general permits for activities in wetlands, therefore, an Individual ARAP would be necessary. ARAPs for activities in wetlands may require some form of compensatory mitigation. It would be necessary to contact the appropriate onsite ORNL Environmental Compliance offices to begin the application permit process and to obtain more detailed information on permitting requirements.

\section{REFERENCES}

Law Engineering. 1993. Quality Assurance Plan for the ANS Project, Site Characterization Activities, Law Engineering, Oak Ridge, Tenn. May.

Reed, P. B. 1988. National List of Plant Species That Occur in Wetlands: Tennessee. U.S. Fish and Wildlife Service Biological Report. NERC-88/18.42. 
Tennessee Department of Environment and Conservation, Division of Water Pollution Control. 1987. Implementing Regulations of the Water Quality Control Act (TN Code Ann. 69-3-100) Chapter 1200-4-7, Aquatic Resource Alteration, revised May 1, 1991, Nashville, Tenn.

United States Army Corps of Engineers. 1987. Wetland Delineation Manual. Tech. Rept. Y-87-1. Waterways Exp. Sta., Vicksburg, Miss. 
APPENDIX A 


\section{Internal Correspondence}

R. A. Brown, Bldg 9201-2, MS-8071, 6-5512

\section{Threetened and endengered foune on the oroposed ANS gite}

1 Visited the proposed ANS site July 26, 1989. The site comprises primerily second-growth herdwood forest. I searched the oree for threatened or endangered species thet mey occur on the Dok Rldige Reservation. No evidence of the presence of such species wes found.

No animal spectes listed as threatened or andangered by the U.S. Fish and Wildiffe Service is known to be prosent on the ORR (Kroodsme 1987). Thersfore, no such species should occur on the proposed site. Of the listed species, the one that hes the greatest potential to be present on the Reservation is the Indiane bot. However, the proposed site has no hebitat that would be particulorly importent to this specles (bottomiend forest edjecent to relatively lerge struems).

The Tennessee Wildlife Resources Agency (TWRA) lists 19 vertebrote species es threatened or endengered ond prohibits by law the intentionel destruction of their hobitat without a permit. Ot the TWRA-listed species, the only ones known to inhebit the Reservotion are the threatened sherp-shinned hawk and the Cooper's hawk. Howover, the shorp-shinned hewk is not believed to occur on the proposed site. The Cooper's hewk is a woodlend hawk that is secretive and very difficult to find during the breeding season (spring and early summer). Although the howk is belleved to be scarse on the Reservation (8.g., one nesting pair per 6 to 8 squere miles). It possibly nests on or in the vicinity of the site. If not used for nesting, the site could provide foraging hebltat for Cooper's hawks nesting elsewhere. The species is more numerous on the Reservation during the fall and winter because birds migrate from northern areas to overwinter in the South. The primary concerm, however, is to protect habitat for Cooper's hawks that nest on the Reservation. The proposed conversion of forest to an industriol facility would reduce the amount of availoble forest habitot ond depress the populations of forest-dwelling species and possibly the Cooper's howk, regordless of whether the hawk nests on or only hunts for prey on the site. 


\section{R. A. Brown}

\section{Pege 2}

August 7, 1989

The Tennessee Wildlife Resources Agency olso lists about 80 vertebrote species as "In need of management" and protects their habitat by low. of these species, the bleck vulture and red-shouldered hawk occur in the vicinity of the site but probebly neither nest there nor find particulerly suitable foroging hobltot thare.

The mountain redbeily doce is on "In need of menegement" fish specles that Inhobits Bear Creak and a fow other struems on the Reservation. The proposed project would not of fect any straam inhebited by this fish species.

\section{REFERENCE}

Kroodsmo, R. L. 1987. Resource menegement plen for the Dek Ridge Reservation, Volume 24: Threstened and endengered animal species. Dok RIdge Notional Laboretory BRNL/ESH-1/V24. 24 pp.

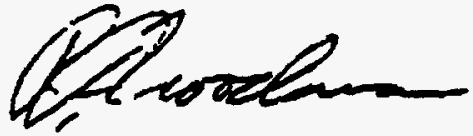

R. Kroodsmo, 1505, M5-6038, 4-7310

Cc: D. G. Jemigan, 日log. 3550, M5-6291, 6-4409 
APPENDIX B 


\section{J. H. Loar}

\section{Survey of Stream Potentfally Inpected by aus Prosect}

On June 30 and July 5, 1989, we survayed the streans potentially affected by the proposed siting of the Advanced Meutron Source (AiS) facflity. The proposed stte straddles the haadwaters of two watersheds, one being Melton Branch and the other a tributary to Beurden Creak. The stroans were surveyed for fish and benthic invertebrates. The fish were sampled using a Satth-Root backpack electrofisher; $H$. G. Ryon operated the unit and an assistant natted any stunned fish. Invertebrates wore qualitatfvely sampled from various habitats (e.g., riffies, pools. leaf packs, otc.) by J. G. Sutth using a D. fram aquatic kick net, and a representative sample was kept for further identification in the laboratory.

In the vicinity of the proposed ANS factlity, Melton Branch is seasonaliy intermittent. with flow during much of the fall, winter, and spring wonths, while during the sumer wonths there are perlods of no flow (Loar 1988). Suffictent flow exists during the nonsumes months to allow the estabi shment of a relatively diverse benthic macroinvertubrato comanity and a small fish population (Rvon 1988; Smith 1988,, 1988b). On June 30, surveys of benthtc Invertebrates and fish in Melton Branch ware inftlated just upstream of Meiton Branch Kilomater 2.1 (MEK 2.1), regular monitoring site for the ORNL Btological Monitoring and Abatement Progran, and continued upstream several hundred moters (Fig. 1). In addition, the invertebrates of a small northeastern tributary, located approximately 150 to $200 \mathrm{~m}$ upstrean of the wetr, were also sampled.

At the downstrean and of the survey reach on Melton Branch (Fig. 1), two species of fish wore collected, the blacknose dace (Rhintchthre atratilut) and creek chub (Semptilus atromaluintus). Both species are common inhabitants of small headwater streans on the Oak Ridge Regervation (ORR) (Ryon and Loar 1988). The fish were very abundant with a lerge percentage being juventle creek chubs. This pattern continued upstraan roughiy $30 \mathrm{~m}$ at which point a water discharge weir provided a stgnificant barrter to fish movement. The only fish taken above the weir was a large adult creek chub, which had the swiming or jumping ability to traverse the swift weter section of the wair. Electroftshing for another $100 \mathrm{~m}$ or so above the weir did not produce any more fish, despite the presence of acceptable habitat. The barrier provided by the weir probabiy prevents significant upstream recolonization following periods when stream flow is inadequate to. support fish.

The tributary to Beerden Craek in the area of the proposed ANS factlity is intermittent. A visual survey conducted in the sumer of 1987 by $M$. G. Ryon indicated dry strean beds at the three major wastern tributaries in the ANS area. The survey on July 5, 1989 found water in all three branches, but an 
J. M. Loar

Page 2

July 26, 1989

electrofishing effort of 30 minutes and covering roughiy $250 \mathrm{~m}$ from the lowest tributary upstream falled to produce any fish (Fig. 1). Numorous salamander larvae were found, princtpally Desmoenthus and Gyrinophilus, which further indicates that fish are soldom if over present.

The benthle invertabrate comenunittes of upper Melton Branch and its suall northoast tributary, and the tributary of Bearden Creak were relatively divarse (Table 1). Most of these taxe occur in both nodorately disturbed and relatively undisturbed streams on the ORR (Suth 1988a, 1988b). Generally, the number of taxa that occur within relativaly pollution-intolerant groups (e.g.. Ephemeroptera and Trichoptera) at any given tive in moderately impacted straams on the ORR, is usually 1latted to no more than one or two taxa. Furthemore, taxa such as Diplectrom and Leptophlebilide are generally collected in only relatively undisturbed straans on the ORR. Thus, these data suggest that this uppar portion of Malton Branch and the tributary of Bearden creok are probably relatively undisturbed. However, further studies would be needed to confirm this.

The plans for drilling monitoring wells and taking core samples in the AUS factlity area require the construction of roads and soms clearing of vegetation. Because the fish fauna in the two streans is ifeted, the impacts should be minimal on the potential fish populations. However, depending upon the extent of disturbance, impacts to benthic invertebrate communities could be substantial. Buffer strips along strean channels should be loft as wide as reasonably possible $(0.9 ., 30 \mathrm{~m}$ or greator) to reduce runoff and to maintain shading of the strean to prevent alearing the natural theral regtme. The construction activitios should be contained with sufficient runoff controls (0.9., sitt curtains) to prevent the addition of significant slit loads to the streams. Also, any road erossing of streans should be done in a mannar that will aliow continued flow during normal ratnfall periods and linit addition of silt. The tapact on the Melton Branch fish comaunity could extend downstream to sections that consistently contain fish if proper silt controls are not used. Also, migration of silt in Bearden Creak could pose additional problems because the stream enters Meiton HIII Reservolr, an area wth greator human contact.

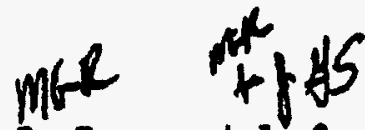

M. G. Ryon and J. G. Smith, BIdg. 1504, MS-6351 (4-7340 or 6-4163)

Attachments

cc: R. L. Kroodsma

P. D. Parr 


\section{Litorature fited}

Loar, J. M. (ed.) 1988. Second annual report on the ORNL Bfological Monttoring and Abatenont Program. Draft ORUL/TH Report. Oak Ridge National Laboratory, Oak Ridge, Tennessee. $475 \mathrm{pp}$.

Ryon, M. G. 1988. Fishes. pp. 203-232. In J. M. Loar (ed.), Second annual report on the ORNL Biological Ponitoring and Abatament Progran. Draft ORNL/TM Report. Oak Ridge National Laboratory, Oak Ridge, Tennessee. 475 pp.

Rvon, M. G. and J. M. Lour. 1988. A checklist of fishes on the Department of Energy Oak Ridge Reservation. J. Tenm. Acad. Sct. 63:97-102.

Smith, J. G. 1988a. Benthic macroinvertebrates. pp. 264-202. IN J. M. Loar (ed.), Second annual report on the ObNL. Blologieal Monitoring and Abatemont Progras. Draft ORNL/TM Report. Oak Ridge National Laboratory, Oak Ridge, Tennessee. 475 Pp.

Smith, J. 6. 1988b. Benthic macroinvertebrates. pp. 109-15b. IN G. R. Southworth (ed.), Ecological evaluation of Bear Creak, 1984-1987. Draft ORNL/TH Report. Oak RIdge National Laboratory, Oak Ridge, Tennesses. 


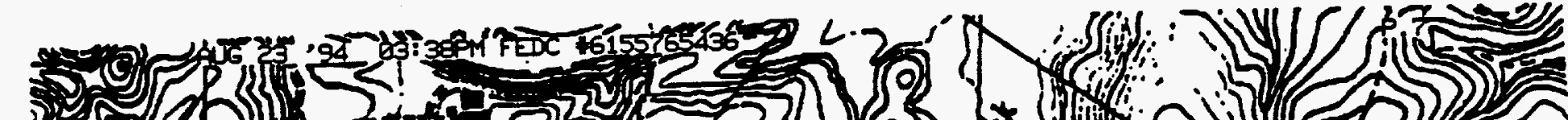

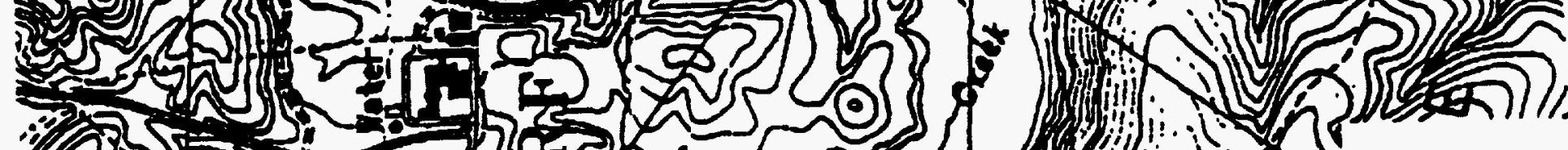
OR

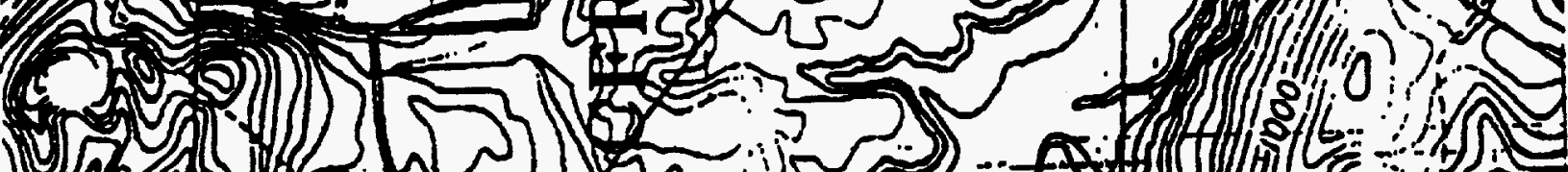
(U) (U) (U)

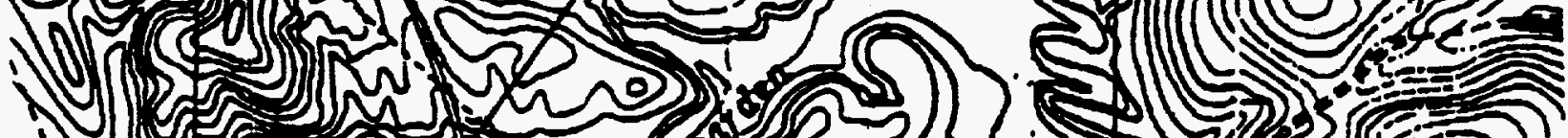

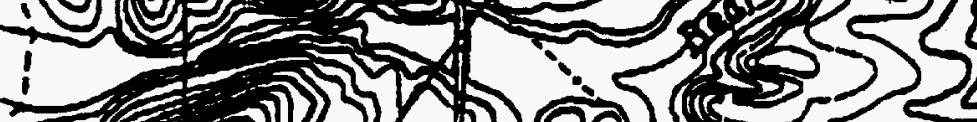

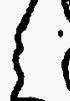

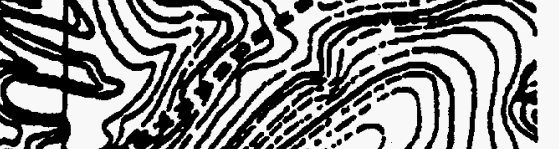

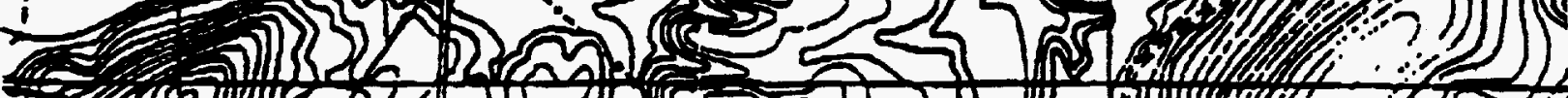

ig(c)

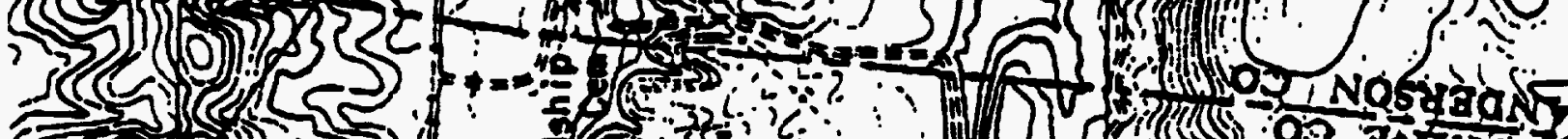

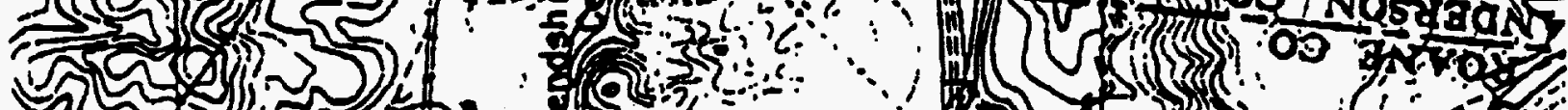

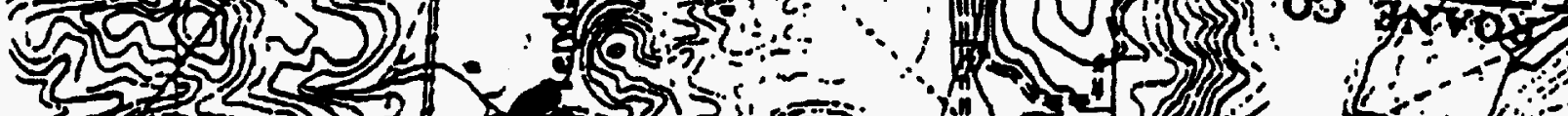

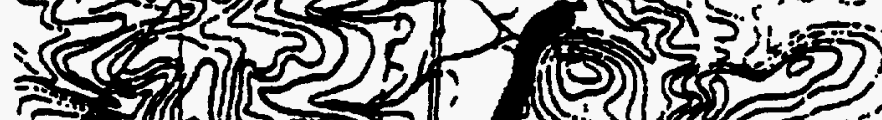

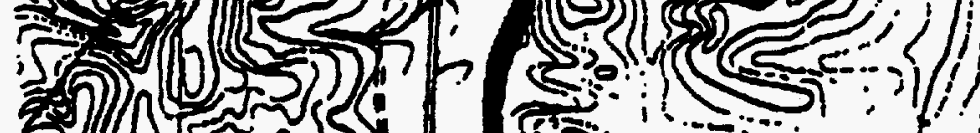
(a)

(1)

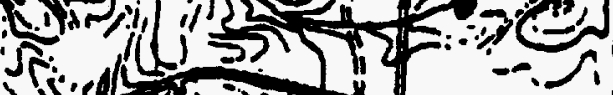

(jiv)

棌)

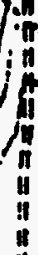
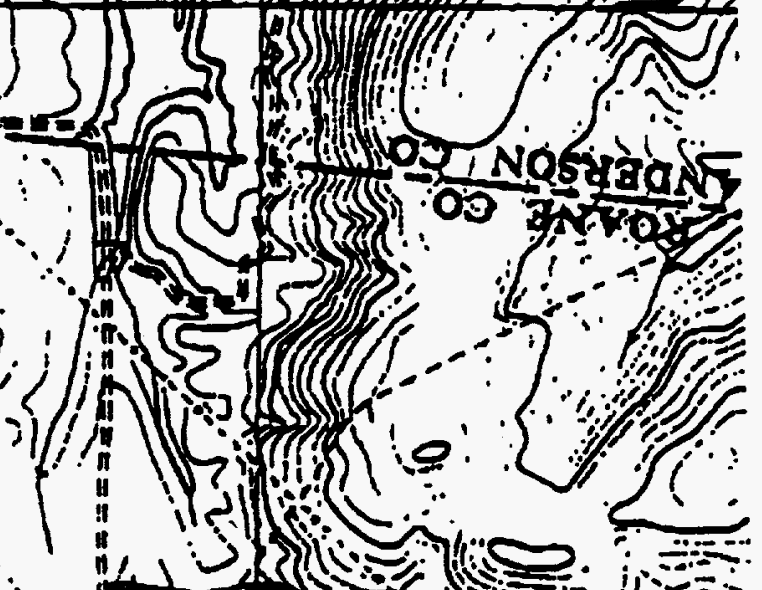

\section{Cosu}

\section{(OA) â)} $\{(x+2)$ (?) $\rightarrow+\infty \rightarrow 0$ 4 ext (3) 7. 1.40 
Table 1. Checklist of the benthic macroinvertebrates collected qual itatively from upper Melton Branch (above kllomater 2.1) and the northwest tributary of Bearden Creak on the Departaont of Energy's Oak Ridge Reservation, June 30 and July 5, 1989, respectively. An " $X$ " indicates the taxon was collected at the respective sito.

\begin{tabular}{|c|c|c|}
\hline Taxon & $\begin{array}{l}\text { Melton } \\
\text { Branch }\end{array}$ & $\begin{array}{l}\text { Bearden Creak } \\
\text { Tributary }\end{array}$ \\
\hline 01igochaeta & $x$ & $x$ \\
\hline Turbellaria & & $x$ \\
\hline $\begin{array}{l}\text { Isopoda } \\
\text { Lfrceus }\end{array}$ & $x$ & $x$ \\
\hline Decapoda & $x$ & \\
\hline Insecta & & \\
\hline $\begin{array}{l}\text { Ephemaroptera } \\
\text { Baetidae } \\
\text { Leptophiebit tae }\end{array}$ & $\begin{array}{l}x \\
x\end{array}$ & $\begin{array}{l}x \\
x\end{array}$ \\
\hline $\begin{array}{l}\text { Odonata } \\
\text { Cordulegastridas } \\
\text { Cordiliegseter } \\
\text { Libelfulidae? }\end{array}$ & $\frac{x}{x}$ & $x$ \\
\hline Plecoptera & $x$ & \\
\hline $\begin{array}{l}\text { Megaloptera } \\
\text { Iltoronis }\end{array}$ & $x$ & $x$ \\
\hline $\begin{array}{l}\text { Trichoptera } \\
\text { Hydropsychidze } \\
\text { Chelmatopsyche } \\
\text { Diplectrons } \\
\text { Bxdropsyche } \\
\text { Limnephilidas } \\
\text { Meophylax } \\
\text { Philopotamidae } \\
\text { Chimarrs } \\
\text { Phryganeidae } \\
\text { oligostomis }\end{array}$ & $\begin{array}{l}x \\
\dot{x} \\
\dot{x} \\
\dot{x}\end{array}$ & $\begin{array}{l}x \\
x\end{array}$ \\
\hline
\end{tabular}


Table 1. (Cont.)

\begin{tabular}{|c|c|c|}
\hline Taxon & $\begin{array}{l}\text { Melton } \\
\text { Branch }\end{array}$ & $\begin{array}{l}\text { Beardan Croak } \\
\text { Tributory }\end{array}$ \\
\hline $\begin{array}{l}\text { Coleoptera } \\
\text { Dytiscidae } \\
\text { Elimidae } \\
\text { Hal tpidae } \\
\text { Hydrophilitee }\end{array}$ & $\begin{array}{l}x \\
x \\
x\end{array}$ & $\begin{array}{l}x \\
x\end{array}$ \\
\hline $\begin{array}{l}\text { Diptera } \\
\text { Chironont dae } \\
\text { Stmul itdae } \\
\text { Tabanidae } \\
\text { Tipulidae }\end{array}$ & $\begin{array}{l}x \\
x \\
x\end{array}$ & $\begin{array}{l}\hat{x} \\
\hat{x} \\
\dot{x}\end{array}$ \\
\hline
\end{tabular}

*A single adult was collected at streansidas thus actual occurrence within the strean is implied but not confirmed.

bonily the case of this taxon was collectad within the creak; however, its occurrence is an indication that this taxon is a perfodic nember of the benthic community within this streas. 


\section{INTERNAL DISTRIBUTION}

1. D. Awl

2. D. Brown

3. J. B. Cannon

4. J. T. Ensminger

5. R. M. Reed

6. B. Rosensteel

7. R. B. Shelton

8-9. M. L. Socolof

10-14. M. C. Wade

15. ORNL Patent Office

16. Document Reference Section

17. Central Research Library

18-20. Laboratory Records

21. Laboratory Records (Record Copy)

\section{EXTERNAL DISTRIBUTION}

22. D. R. Bohi, Director, Energy and Natural Resources Division, Resources for the Future, $1616 \mathrm{P}$ Street, N.W., Washington, DC 20036.

23. Thomas E. Drabek, Professor, Department of Sociology, University of Denver, Denver, Colorado 80208-0209.

24. C. D. MacCracken, President, Calmac Manufacturing Corporation, 101 West Sheffield Avenue, P.O. Box 710, Englewood, New Jersey 07631.

25. J. B. Shrago, Director, Office of Technology Transfer, 405 Kirkland Hall, Vanderbilt University, Nashville, Tennessee 37240.

26. G. F. Sowers, P.E., Senior Vice President, Law Companies Group, Inc., 114 Townpark Drive, Suite 250, Kennesaw, Georgia 30144-5599.

27. C. M. Walton, Paul D. and Betty Robertson Meek Centennial Professor and Chairman, Department of Civil Engineering, College of Engineering, University of Texas at Austin, Cockrell Hall, Suite 4.2, Austin, Texas 78712.

28. Office of Assistant Manager for Energy Research and Development, DOE-ORO, P.O. Box 2001, Oak Ridge, Tennessee 37831-8600.

29-31. OSTI, U.S. Department of Energy, P.O. Box 62, Oak Ridge, Tennessee 37831. 